\title{
Poda Na Lima: Islamic Character Based on Local Wisdom in Angkola-Mandailing
}

\author{
Rohman', Rica Umrina Lubis ${ }^{2}$ \\ Sekolah Tinggi Agama Islam Negeri Mandailing Natal ${ }^{1,2}$
}

Korespodensi dengan penulis:

Rohman: Telp. 085360259819;

E-mail: rohman@stain-madina.ac.id

Keywords:

Islamic

character, Local

Wisdom, Poda

Na Lima
Kata kunci:

Karakter Islam,

Kearifan Lokal,

Poda Na Lima

\begin{abstract}
Poda Na Lima is Angkola-Mandailing local wisdom means five advices which are used as a basis for the formation of islamic character of its people in their life. This local wisdom has dealt with islam such as to maintain cleanliness and purity both mentally and physically. This study explains about how islamic character based on "Poda Na lima" local wisdom in AngkolaMandailing community. The five basic values of Poda Na Lima are paias rohamu (the obligation to purify your hearth), paias pamatangmu (the obligation to purify your body), paias parabitonmu (the obligation to clean your clothes), paias bagasmu (the obligation to clean your house) and paias pakaranganmu (the obligation to clean the environment). This type of research was qualitative using a qualitative descriptive approach. Data collection techniques are done by observation, in-depth interviews and literature review that examines directly about Poda Na Lima. Data analysis used systematically starting from data collection, data presentation, data reduction to draw conclusions. The result of this study shows that those traditions were very important identities to of Angkola-Mandailing community particularly to perform a good character and personalities to build a clean and healthy community order. And also become a guideline and foundation of life held by every Angkola-Mandailing ethnic group in managing life.
\end{abstract}

\begin{abstract}
Abstrak
Poda Na Lima merupakan kearifan lokal etnik Angkola-Mandailing yaitu lima nasehat yang digunakan sebagai dasar untuk pembentukan karakter Islami dalam kehidupan masyarakatnya. Kearifan lokal ini sejalan dengan tujuan Islam yakni menjaga kebersihan dan kesucian baik secara lahir maupun batin. Penelitian ini menjelaskan tentang bagaimana karakter Islami berdasarkan kearifan lokal Poda Na lima pada masyarakat Angkola-Mandailing. Lima pokok yang terkandung pada Poda Na Lima yaitu paias rohamu (kewajiban untuk menyucikan hati), paias pamatangmu (kewajiban membersihkan anggota tubuh), paias parabitonmu (kewajiban untuk membersihkan pakaian), paias bagasmu (kewajiban untuk membersihkan rumah) dan paias pakaranganmu (kewajiban untuk membersihkan lingkungan). Jenis penelitian ini adalah kualitatif dengan menggunakan pendekatan
\end{abstract}


deskriptif kualitatif. Teknik pengumpulan data dilakukan dengan observasi, wawancara mendalam dan tinjauan pustaka yang mengkaji langsung tentang Poda $\mathrm{Na}$ Lima. Analisis data digunakan secara sistematis mulai dari pengumpulan data, penyajian data, reduksi data hingga penarikan kesimpulan. Hasil penelitian ini menunjukkan bahwa Poda Na Lima sebagai tradisi merupakan identitas yang sangat penting bagi masyarakat Angkola-Mandailing terutama untuk mewujudkan karakter dan kepribadian yang baik dalam rangka membangun tatanan hidup masyarakat yang bersih dan sehat. Pada saat yang sama juga menjadi pedoman dan landasan hidup yang dipegang oleh setiap kelompok etnik Angkola-Mandailing dalam menata kehidupan.

\section{INTRODUCTION}

Indonesia as the largest archipelago in the world is known have a wide variety of ethnics, cultural, religious, traditions and local wisdom. ${ }^{1}$ The way of life, philosophy and values of its local wisdom have fundamentally shaped its own character for its people. Therefore, Indonesia has a variety of values that underlie the patterns of life of the people in it. Problems then arise that make educators explore the discourse of character education so that everyone has a foundation of values as a reference for themselves in acting in line with the ideals of the nation and state. And as Indonesia currently requires human resources who's character are religious, nationalist, independent, mutual cooperation, and integrity. ${ }^{2}$

Strengthening the above ideals is one of the discourse of character education development that needs attention is related to local wisdom. Character education based on local wisdom becomes important to be applied so that students and the community can not be saparated from their cultural roots and identity and westernized and arabian culture are not accepted immediately without any filter.

Local wisdom is the intelligence possessed by ethnic groups in a society that is obtained through life experience. ${ }^{3}$ Local wisdom is also in-mind and contextual which is able to accumulate and integrate social context with existing values. ${ }^{4}$ Based on the two defininitions

\footnotetext{
${ }^{1}$ See Yudi Latif, Negara Paripurna: Historisitas, Rasionalitas, dan Aktualitas Pancasila, Fifth edition, (Jakarta: PT Gramedia Pustaka Utama, 2015), p. 252.

${ }^{2}$ Kementerian Pendidikan dan Kebudayaan, Modul Pelatihan Penguatan Pendidikan Karakter bagi Komite, 2017.

${ }^{3}$ Rahyono, FX, Kearifan Budaya dalam Kata, (Jakarta: Wedatama Widyasastra, 2009), p.11."Kajian Kearifan Lokal Masyarakat dalam Pengelolaan Sumber Daya Alam dan Lingkungan", Prosiding Seminar Nasional Penelitian, Pendidikan dan Penerapan MIPA, Fakultas MIPA, Universitas Negeri Yogyakarta, 2009.

${ }^{4}$ Sternberg, Robert J, Wisdom and Gifiedness dalam Shavinina, Larissa V, Ferrari, Michel Ed. Beyond Knowledge Extra Cogtitive Aspects of Developing Hight Ability, (New Jersey: Lawrence-Erlbaum, 2004). p. 10.
} 
above, it can be understood that local wisdom is the uniqueness of each local culture in the form of wisdom, excellence or intelligence as a result of the experience, appreciation, and thoughts of previous people who later become the value of virtues.

The Angkola-Mandailing community as one of the ethnic groups living in the land of North Sumatra which has a local wisdom called Poda Na Lima. Poda Na Lima which means five advices become the philosophy and foundation of life held by every Angkola-Mandailing ethnic group in managing life. Then the five basic values of Poda Na Lima are paias rohamu (the obligation to purify your soul and the things that disfigure it, such as; robbing others' and governances), paias pamatangmu (the obligation to purify your body both mentally and physically), paias parabitonmu (the obligation to clean your clothes), paias bagasmu (the obligation to clean your house, furnitures and avoid getting them all through unright way) and paias pakaranganmu (the obligation to clean the environment such as; trash,drug and so on). 5

Poda Na Lima becomes interesting to be investigated further because in terms of value it is related to the objectives of Islam. In addition, Poda Na Lima is considered to be relevant to the context of today's life, where cleanliness and rubbish are still a fundamental problem in Indonesia. Hasbullah citied the data from the Minister for the Environment that Indonesia produces 151.921 million $\mathrm{kg}$ of waste every day and $20 \%$ is unhandled so they pollute the environment which then becomes the source of various diseases. ${ }^{6}$ This is caused by the uneducated community in managing waste and environmental cleanliness. ${ }^{7}$ And lately with the emergence of Corona Virus Disease 19 (Covid-19) or corona virus as a pandemic in the world requires everyone to pay more attention to keep clean and healthy lifestyles.

Poda Na Lima as local wisdom is the right source of values to build a clean and healthy community order. Poda Na Lima as the Angkola-Mandailing ethnic way of life has a very noble instructive power and becomes a guideline since the kings and their sutan were established. ${ }^{8}$ It is different, for example, with other local wisdoms which can be said to be syncretistic and contain myths as described by Husni Thamrin in his research on Malay local wisdom in maintaining environmental harmony. ${ }^{9}$ Likewise, Hari Bakti Mardikantoro's research shows

5 Basyral Hamidi Harahap, Siala Sampagul: Nilai-nilai Luhur Budaya Masyarakat Kota Padang Sidimpuan, first edition, (Bandung: Pustaka, 2004), p. 130.

${ }^{6}$ Hasbullah, et all., "Analisis Pengelolaan Sampah di Kota Subulussalam Tahun 2017", Jurnal Jumantik, Vol. 4, No. 2, 2019. p. 135.

7 Muchammad Zamzami Elamin, et all., “Analisis Pengelolaan Sampah pada Masyarakat Desa Disanah Kecamatan Sreseh Kabupaten Sampang", Jurnal Kesehatan Lingkungan, Vol. 10, No. 4, 2018. p. 369.

8 The result of inteview with Askolani Nasution, Akademic and Mandailing Natal traditional figure, Januari 2020.

${ }_{9}^{9}$ Husni Thamrin, "Revitalisasi Kearifan Lokal Melayu dalam Menjaga Harmonisasi Lingkungan Hidup”, Jurnal Toleransi: Media Komunikasi Umat Beragama, Vol. 6, No. 1, 2014. p. 92. 
that there are still some animistic contents in Javanese local wisdom in the Samin community which has unclear foundation in Islamic teachings. ${ }^{10}$

Poda Na Lima as a local wisdom is the expressions of giving advice and order to clean ourself and environment. The word choice of paias means cleanse for each of the five mentioned target objects namely heart, body, clothes, house and environment shows that this local wisdom wish personal hygene. Clean in Islamic terminology is the beginning of the birth of purity. So the value in it is related to Islam. The philosophy of Poda Na Lima always teach a clean life both spiritually and physically including the heart to avoid jealousy, envy or grudging against others, so that to the body, we have to maintain our body clean. The evidence of Islamic commitment in the issue of cleanliness can be seen through fiqh studies, almost begin with chapters of thaharah or studies of purification. ${ }^{11}$ In a hadith it is mentioned that cleanliness is part of the perfection of faith.

Different from the Javanese's expression such as in the research of Budiyono et al., It was mentioned aja dumeh (don't be arrogant), tepa selira (tolerance), Mawas diri (selfawareness), budi luhur (nobility), wani tombok (dare to bear the loss for pride), mendhem jero mikul dhuwur (shutting the hole as deep as carrying up), gemi, nastiti (thrifty and careful), ngatiati (always be careful), jer masuki mawa beya (if you want to succeed, it will cost you) ajining dhiri saka obahing lathi (pride depends on what he says). ${ }^{12}$ These expressions do not contain direct orders to clean up like in the local wisdom of Poda Na Lima above.

Islam with its noble ideals, wants to change the order of people's lives which was corrupted by the impurities of human nature. Purity in Islam is actually a reflection of the cleanliness of the heart, mind, limbs and the environment. Therefore Islam as a perfect religion has underpinned the lives of its adherents with purification and personal hygiene. and Allah states in Al-Qur'an "And Allah loves those who are purify themselves" (Surah Al-Taubah: (9): 108). ${ }^{13}$ Accordingly, in Islamic perspective Poda Na Lima is seen as an instrument to achieve a perfect human being with cleanliness and purity of both physically and mentally.

So from the perspective above, the phenomenon that occurs in the field, it appears that the crystallization of Poda Na Lima values has increasingly been dissapperaed by new cultures that affect lifestyles at every level of society and also the foundation of life and values of the Angkola-Mandailing community. Students at school who were initially obligied to memorize the points of Poda Na Lima later now no anymore. Longer became the obligation so that many students did not know what is the meaning of Poda Na Lima. If at the beginning of every

10 Hari Bakti Mardikantoro, "Bahasa Jawa sebagai Pengungkap Kearifan Lokal Masyarakat Samin di Kabupaten Blora", Jurnal Komunitas, Vol. 5, No. 2, 2013. p. 201.

11 This can be seen from the books written by fiqh scholars.

12 Budiyono, et all., "Menggali Nilai-nilai Kearifan Lokal Budaya Jawa sebagai Sumber Pendidikan Karakter", Prosiding Seminar Nasional Bimbingan dan Konseling, Vol. 1, No. 1, 2017. p. 94-101.

13 See Al-Qur'an Surat 9:108. 
schools it was recommended to display Poda Na Lima artifacts on the walls and the school gates, now it seems not many use them in their schools. ${ }^{14}$

This condition reflects that the community no longer cares about the local wisdom that becomes their spirit and identity. So it requires serious attention both academics and education policy makers. In this context the author tries to take a role by conducting a study how islamic character based on "Poda $\mathrm{Na}$ lima" local wisdom in Angkola-Mandailing community.

\section{METHOD}

This research was conducted over two months from the beginning of January to the end of March 2020. The location of the research observation was from the Panyabungan city to East Panyabungan which borders South Tapanuli. This type of research was qualitative using a qualitative descriptive approach. The focus of research on Poda Na Lima as a source of Angkola-Mandaling ethnic values. Data collection techniques are done by observation, indepth interviews and literature review that examines directly about Poda Na Lima. Data analysis used systematically starting from data collection, data presentation, data reduction to draw conclusions. Meanwhile, to test the validity of the data, researchers used triangulation of data sources and triangulation of data collection techniques by Sugiyono. ${ }^{15}$ It can be seen in the following picture.

Picture 1. Triangulation of Data Sources

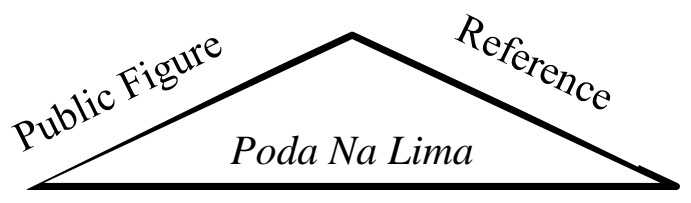

The Practice of Poda Na Lima

Picture 2. Triangulation of Data collection techniques

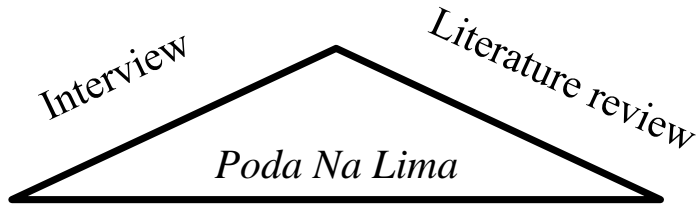

Observation

\footnotetext{
2020.

15 Sugiyono, Metode Penelitian Pendidikan: Pendekatan Kuantitatif, Kualitatif, dan RED, Seventh edition, (Bandung: Alfabeta, 2010), p. 273.
}

${ }^{14}$ Observation result in Panyabungan city and also supported by Askolani Nasution statement, 


\section{DISCUSSION}

\section{Character in Islam}

Islam is a religion it is believed to be the way to achieve the salvation of the world and the hereafter. The teachings contained in Islam is not only in the form of worship practices to Allah SWT physically, but also includes views on life, lifestyle, behavior in dealing with fellow creatures. ${ }^{16}$ Besides containing formal law, Islam also provides guidelines on how every human being should behave and act among fellow creatures and environment in order to achieve a perfect life which in Islamic vocabulary is called morals.

Character becomes a determinant of the quality of a Muslim's in carrying out every Islamic teaching. Character education in Islam is interpreted as moral education. Ontologically character can be seen in terms of its etymology, the word akhlak is plural from khuluq. In Qur'an the word khuluq is placed as a word of praise to the Prophet Muhammad SAW, and Allah states in Al-Qur'an "And indeed, you are of a great moral character" (QS . Al-Qalam (68) : 4). ${ }^{17}$

According to Nurcholish Madjid in Budhy Munawar Rachman, character in Islam is related to the essence of the origin of human being. ${ }^{18}$ Akhlak is the plural form from khuluq is basically has the same root with Khâliq and makhluq. Khaliq means creator and makhluq is created, then khalq is a form of mashdar (verbal noun ), it means the act of creation. So from this it can be seen that the concept of character in Islam has a relation with the origin of human beings. ${ }^{19}$ If there is an ascription like "something is ethical" is never said that as khuluqi but akhlaqi, because in the character there are many ingridients, and never be singular. ${ }^{20}$ This implies that character becomes a fundamental essence in Islam.

In line with M. Quraish Shihab also stated that character is interpreted as the diverse manners or human behavior. To prove this the word of Allah SWT states "Indeed, your effort are diverse" (QS. Al-Lail (92): 4). ${ }^{21}$ Sihab said that, this is the diversity of human behavior is produced as a good and bad value in accordance with the potential given to him.

Ibn Maskawaih said that character is a mental character, soul or spirit condition that encourages him to act without thinking an considering first. Al-Ghazali interpreted that character is a embedded quality in the human soul then reflect to human mind and

16 Machasin and Abdul Wahid Hasan, Islam Dinamis Islam Harmonis: Lokalitas, Pluralisme, Terorisme, First edition. (Yogyakarta: Penerbit \& Distribusi, LKiS, 2011), p. 15.

17 See Al-Qur'an Surat 68:4.

18 Nurcholish Madjid, "Akhlak: Esensi Kejadian Manusia", in Budhy Munawar Rachman, Ensiklopedi Nurcholish Madjid, First edition, (Jakarta: Teraju, 2005), p. 30.

${ }^{19}$ Ibid., p. 31.

${ }^{20}$ Ibid., p. 31.

${ }^{21}$ M. Quraish Shihab, Wawasan Al-Qur'an: Tafsir Tematik atas Pelbagai Persoalan Umat, First edition, (Bandung: Mizan, 2013), p. 336. 
condition. Ibn Qayyim said, character are temperaments or qualities that describe the inner nature of every human being. 22

Based on the above opinion, it can be stated that character become an essential thing in Islam. character become a description of the personality of every human being. Character also encourage everyone to do every activity. In the hadith of the prophet states that "I have only been sent to perfect morals" (HR. Imam Malik). Thus it can be concluded that in order to become a real person must have morality.

As a description of the personality of every Muslim in his actions, Islam also classifies characters into three objects of character targets. First, characters towards Allah SWT, second characters towards human beings, third, characters towards the environment. ${ }^{23}$ Characters towards Allah SWT is the recognition and awareness that there is no god but Allah. God is the source of moral perfection. ${ }^{24}$ So to achieve this perfection, humans are always encouraged to glorify Him, because everything that comes from Him is good, right, pure, beautiful and perfect. Allah SWT states in Al-Qur'an "And say," (All) praise is (due) to Allah, He will show you His signs, and you will recognize them. And your Lord is not unware of what you do ", (QS Al-Naml (27): 93).

Characters towards human beings in Islamic teaching comes from the view that every human being has the same position alongside of Allah SWT. Islamic guidance that is related to this character are every human should maintain mutual respect of each other. Both in physical terms by not killing, hurting the body, and non-physical as taking wealth without good reason, and hurting the people's feeling both directly and indirectly, such as telling someone's disgrace to others. ${ }^{25}$ Allah SWT states in Al-Qur' an"Kind speech and forgiveness are better than charity followed by injury. And Allah is free of need and Forbearing.(QS Al-Baqarah (2): 263).

Characters towards the environment in Islam refers to how humans put themselves with their surrounding such as animals, living yards, plants and other lifeless objects. According to M Quraish Shihab, characters towards the environment refer to the function of humans as Caliphs. Caliphate in this context requires their attention as a natural leader who can save this nature from damage and total destruction and establish a good relation among creatures. The connotation meaning of Caliph is as a guardian, keeper and advisor so that every creatures can run well based on the principles and objectives of its creation, as a mercy to the worlds. Allah SWT states in Al-Qur' an "And We have not sent you, (O Muhammad), except as a mercy to the worlds" (Surah Al-Anbiya (21): 107).

\footnotetext{
${ }^{22}$ Ending Saifudin Ansari, Wawasan Islam, Third Edition, (Bandung: Pelajar, 1982), p.26.

${ }^{23}$ M. Quraish Shihab, Wawasan Al-Qur'an: Tafsir Tematik atas Pelbagai Persoalan Umat..., p. 348.

24 Ibid., p. 349.

${ }^{25}$ Ibid., p. 354.
} 
The description of the characters above if we compare with the general understanding is as character or behavior. ${ }^{26}$ It can be understood that character in Islamic terminology has deep understanding. Its more than just about behavior that is shown through deeds. Character in Islam is described above actually has a spiritual dimension that is humans will bring the prosperity and peace for all creatures in the world.

\section{Local Wisdom Values}

Value is basically a belief that empower a person or group of people to do something. Adisusilo said, value is actually has good quality, useful and true according to every person or group who believe it. ${ }^{27}$ Daroe Iswatiningsih stated that values are not just beliefs but also as a center of everyone's life. ${ }^{28}$ While M. Nikman Naser stated that the value is an assumption that according to someone is good to run in life so it tends to be loved, realized and applied in everyday life. ${ }^{29}$ Because of the differences it can be understood that value is basically the result of creation which is then believed to be a truth.

Values that are contain truth then carry on by everyone or society who believe in them, because they always color every life's activity. Such values will survive if become guidelines that can deliver humans to the safety of life. So, value is very valuable in human life.

Each person or group from each region has a value that they hold, so that their way of life and mindset which is set by the value system of what do they carry on. From this understanding local wisdom is emerged. Where each region creates its own local wisdom based on the value system that they apply.

Local wisdom is something that has big potential to be developed in the process of character education for students and the community. Considering local wisdom is basically born from the appreciation of the ancestors who describe the ideal life, love peace and balance between nature and the environment. The capacity of value in each activities and traditions such as traditional ceremonies and giving advice are the realization of local wisdom has local spirit and strong magnet in the formation of character and way of life in each area. The values are contained in the tradition are the wisdom inherited from the ancestors.

In addition, Rahyono said that local wisdom is the human intelligence possessed by certain ethnic of group. This intelligence is the result of experience of the community. The formula is the more experience people have, the more wisdom they have.30 While local

${ }^{26}$ See Indonesian Dictionary.

27 S. Adisusilo, Pembelajaran Nilai Karakter (Jakarta: Rajawali Pers, 2012), p. 56.

${ }^{28}$ Daroe Iswatiningsih, "Penguatan Pendidikan Karakter Berbasis Nilai-nilai Kearifan Lokal di Sekolah", Jurnal Satwika (Kajian Ilmu Budaya dan Perubahan Sosial), Vol. 3, No. 2, 2019, p.156.

${ }^{29}$ M. Nikman Naser, "Konselor dalam Penguatan Nilai dan Moral: Strategi Membentuk Generasi Religius", Jurnal Ilmiah Syiar, Vol. 19, No. 01, 2019. p. 34.

30 Rahyono, F.X. Kearifan Budaya dalam Kata, (Jakarta: Aksara Baru, 2009), p. 15. 
wisdom according to Sodiq A. Kuntoro is a word that is used to indicate that there are some components such as nobleness, high values, truth, goodness and beauty. They become the guidance of making the pattern of relationship among the people as the base of vision of life. 31

Values in local wisdom according to Nuraini Asriati is as a conflict reducer among citizens. This value contains policy that is able to guide the community to live in harmony, mutual help, respect, love and pride in one's own identity. In addition, the values of local wisdom are also able to guide the community to filter foreign cultures and be able to carry out the ideals of a balanced national life, both physically and mentally. ${ }^{32}$

Based on some of the explanations above, it can be concluded that local wisdom is the identity of every community that is shows that the community is qualified, wise and at the same time unique. The vaues are contained in local wisdom have strong spirit to empower every person or community to a better direction and respectable in life in line with the ideals of their predecessors as evidenced by their daily behavior and actions.

\section{Poda Na Lima : Angkola-Mandailing Local Wisdom}

The Angkola-Mandailing community is one of the ethnic groups living in North Sumatera ${ }^{33}$ has the concept of Poda Na Lima which means five advices, are the philosophy and the way of life as a local wisdom that carry on by every Angkola-Mandailing ethnic in daily life. These five values are paias rohamu (the obligation to purify your hearth), paias pamatangmu (the obligation to purify your body), paias parabitonmu (the obligation to clean your clothes), paias bagasmu (the obligation to clean your house) and paias pakaranganmu (the obligation to clean your environment $)^{34}$

Historically, Poda Na Lima is as the moral foundation of the Angkola-Mandailing and the result of the reflection and the way of life of the ancestors of Angkola-Mandailing during the time of the Sutan and the kingdoms of Angkola-Mandailing were established. ${ }^{35}$ The results

31 Sodiq A. Kuntoro, “Konsep Pendidikan Berbasis Kearifan Lokal Sebagai Dasar Pembentukan Karakter Bangsa", Prosiding Seminar Nasional Ilmu Pendidikan: Pengembangan dan Pengelolaan Pendidikan Berbasis Kearifan Lokal, First Edition, (2012), p. 3.

32 Nuraini Asriati, "Mengembangkan Karakter Peserta Didik Berbasis Kearifan Lokal Melalui Pembelajaran di Sekolah", Jurnal Sosiologi Pendidikan dan Humaniora, Vol. 3. No. 2. Oktober 2012. p. 107.

33 The position of the Angkola-Mandailing region is on the border of the provinces of North Sumatra and West Sumatra. The Angkola-Mandailing community is the third largest sub-ethnic with 13.54 percent in North Sumatra after the ethnic Toba 20.63 percent and Javanese 33, 47 percent of the total population of 12,985,075. See Alimuddin Sidabolak, et all., Hasil Sensus Penduduk 2010 Provinsi Sumatra Utara: Data Agregat per Kabupaten/Kota, Badan Pusat Statistik Provinsi Sumatra Utara 2010, p. 9-13.

${ }_{34}$ Basyral Hamidi Harahap, Siala Sampagul: Nilai-nilai Luhur Budaya Masyarakat Kota Padang Sidimpuan, First Edition, (Bandung: Pustaka, 2004), p. 130.

${ }_{35}$ Certainly no name or figure has been found that originally formulated Poda Na Lima in the Angkola-Mandailing community, but generally the community believed that Poda Na Lima was the legacy of their forefathers without knowing who and when Poda Na Lima appeared in people's lives. This information is concluded by the author based on studies of various related books and discussions with Askolani Nasution and Suheri Saputra Rangkuti, 2020. 
of these reflections are the realization of the Angkola-Mandailing community who inspire the ideal life. 36

To sum up the way of life of the ancestors of Angkola-Mandailing ethnic which is embodied in Poda Na Lima, Willem Iskander or Sati Nasution is known as a Mandailing educator figure. Iskander, who had received formal education in Netherlands and several segments of his life has a contact with the government bureaucracy, changes the patterns and the way of life of the Angkola- Mandailing community and empower the youth to take formal education. ${ }^{37}$ Through the verses of poetry described, Iskander invite the community to give the attention of importance of education through Poda Na Lima.38

Unlike the local wisdom in other areas, generally every local wisdom that they have contained in the written manuscripts by the traditional leaders predecessor. Poda Na Lima as an idea and thought that has become a tradition in the Angkola- Mandailing community through de facto is not found in the written manuscripts by the traditional figures as their heritage. But dejure it was recognized as an idea of thought and appreciation of the origin of the ancestors of Angkola- Mandailing. According to Basyral Hamidi Harahap, this is because the Angkola - Mandailing ehtnic had not been accustomed in writing tradition from the beginning, but they always do markobar or oral tradition in the process of interaction with others.

Since the long time ago Angkola - Mandailing community were like to give advice. It is well known by the terms of marsipaingot and mangalehen poda. This oral tradition is passed down from generation to generation, so it is not surprising that stories about ancestral wisdom are only conveyed through stories by old people. ${ }^{39}$

Poda Na Lima in its development become compulsory memorization of students at schools in Angkola- Mandailing and has become a tradition that has been crystallized in the mind of people Angkola-Mandailing, furthermore become a cultural symbol and written in the form of artifacts. ${ }^{40}$ Teachers at schools through the philosophy of Poda Na Lima always teach a clean life both spiritually and physically including environmental cleanliness in accordance with the value of Poda Na Lima. At this point it can be stated that the philosophy

\footnotetext{
${ }^{36}$ See Basyral Hamidi Harahap dan Hotman M. Siahaan, Orientasi Nilai-nilai Budaya Batak: Suatu Tindakan Terhadap Perilaku Batak Toba dan Angkola Mandailing, (Jakarta: Sanggar Williem Iskander, 1987), p. 113.

37 Evidence of Willem Iskander's struggle in the field of Education was the establishment of a teacher school (Kweekschool) in Mandailing precisely in the village of Tano Bato during the Dutch colonial period. In his history, he was so successful because of his teacher school was rated as the best teacher school in the Indies at that time. See: Basyral Hamidi Harahap and Hotman M. Siahaan, Orientasi Nilai-nilai Budaya Batak: Suatu Tindakan Terhadap Perilaku Batak Toba dan Angkola Mandailing..., p. 97.

38 See Willem Iskander, Sibulus-bulus Sirumbuk-rumbuk, Basyral Hamidi Harahap translation, 44th edition, (Jakarta: Puisi Indonesia, 1987), p.15.

39 Basyral Hamidi Harahap, Siala Sampagul, (Bandung: Pustaka 2004), p. xi.

40 The result of Interview with Askolani Nasution, 2020.
} 
of Poda Na Lima through its meaning has te same concept with teachings of Islam, where every human should maintain cleanliness and purity both mentally and physically, including the heart to avoid jealousy, envy or grudging against others, so that to the body, we have to maintain our body clean. In a hadith it is mentioned that cleanliness is part of the perfection of faith.

\section{Islamic Values in Poda Na Lima}

Islam is basically a universal religion, it is open to any kind of teaching outside Islam if the condition takes the true direction according to the teachings of Islam itself. So Islam is radical egalitarian. ${ }^{41}$ Islam through its teaching values has a functions as a basis in creating the culture, principles and way of life of people who adhere it wherever they are, that makes Islam flexible in dealing with culture and local wisdom. So that Islam is shâlihun li-kulli zamânin wa-makân. It is suitable used in the time and place where Islam is practiced. 42

\section{1) Paias Rohamu}

The hearth in Islam is called qalbu. The root of the word qalbu is taken from the word qalb. Qalb is the mashdar of the word qalaba yaqlibu, qalaba means reverse or turn away. ${ }^{43}$ Hadith of the Prophet Muhammad (Peace be upo Him) said "Remember that you are a lump of flesh if it is good, then whole of your body (your life) will be good and if it is broken then whole of your body (your life) will damage" , (HR. Bukhari).

In the view of Sufis ${ }^{44}$ hearth is classified as a conscience. From this word then comes the term conscience. In Arabic the meaning of conscience is light. Just as the spirit comes from rûh, and the body of jism. So the word conscience comed from nûr means light. According to Nurcholish Madjid, the reason why the human heart is called conscience because it is a primordial capital from God as the light of human life, so it is referred to as azali capital. ${ }^{45}$

In Qur'an gives an explanation that conscience serves as a pointing device on the right and wrong way. Allah SWT states "And (by) the soul and He who proportioned it. And inspired it (with discernment of) its wickedness and its righteousness. He has succeeded who purifies it. (QS . AshShams: ( 91 ): 7-9). Through this information, it is clear that Islam views the soul as a vital human being. So it becomes a determinant of the quality of one's self.

${ }^{41}$ Nurcholish Majid, Tradisi Islam: peran dan fungsinya dalam pembangunan di Indonesia (Jakarta; Dian Rakyat: Paramadina ;, 2008), 13.

42 Machasin and Hasan, Islam Dinamis Islam Harmonis, 55.

${ }^{43}$ Mahmud Yunus, Kamus Arab-Indonesia, (Jakarta; PT Mahmud Yunus Wadzuryah, 1989), p. 328.

${ }^{44}$ Sufi is a term for people who study Sufism, the activities are focused generally on purification of heart and soul. See H.M. Amin Syukur, dkk., Tasawuf Kontekstual; Solusi Problem Manusia Modern, Second Edition (Yogyakarta; Pustaka Pelajar, 2002), p.13.

45 Nurcholish Majid and Budhy Munawar Rachman, Ensiklopedi Nurcholish Madjid: Pemikiran Islam Di Kanvas Peradaban, First Edition. (Jakarta: Paramadina, 2006), p. 227. 
The meaning of paias rohamu is the obligation to purify your hearth. Each individual is demanded to purify their hearth of anyhing disfigure it. This context is related to education. Before learning something a person need to clean his soul so that it will be easy to receive all lessons. In the Sufism, the heart is divided into three criteria, the first qalbun salim a healthy heart, the second qalbun mayyit a dead heart, the third is qalbun maridh a sick heart ${ }^{46} \mathrm{~A}$ healthy heart is characterized by a generous attitude, flexible to anyone and always feel curious to study science. While the sick heart is characterized with arrogant, envy, riya and so on. Likewise a dead heart, this indicates that his heart contain a lot of desire makes him far from the truth. The result of this kind of heart is a person will find difficulty to judge things objectively, so that everything is useless unless benefit him.

Paias rohamu is the tradition of the Angkola-Mandailing people in order to give advice to a child when they want to study. Then the advice to purify the heart from arrogant and the desires become the key to achieve success. On the other hand, paias rohamu is also addressed to people who are still telling the shame of others. Bingka-bingka practice ${ }^{47}$ becomes a negative stigma that is often addressed to Angkola- Mandailing people who act jealousy when they see their neighbors and relatives succeed in their efforts. So that is the purpose to clean the heart to create good social interaction.

1) Paias Pamatangmu

After the heart is taken care and cleaned, the body as a place of the heart must also be kept clean in order to avoid various types of disease. In Islam, physical cleanliness and purity become processions and conditions in carrying out worship to Allah SWT. Allah SWT states in Al-Qur'an "(Remember) when He overwhelmed you with drowsiness (giving) security from Him and sent down upon you from the sky, rain by which to purify you and remove you the evil (suggestion) of Satan and to make steadfast your hearths and plant firmly thereby your feet." (Surat al-Anfal: ( 8 ) : 11).

The meaning that can we take from the above verse is water is the most important medium to clean the body. The importance of maintaining body hygiene as an effort to avoid all kinds of diseases. When the body is dirty, all kinds of diseases will easily infect humans. Medically, the human body will be categorized as healthy if it is cleaned regularly. For example bathing, cleaning hands before and after doing activities, brushing teeth after eating and washing feet before bed. So with the healthy body we will easily accept life's lessons well.

The efforts to clean the body are basically the nature possessed by every human being. Hadith of the Prophet Muhammad (Peace be upon Him) said "There are five fitrah,

\footnotetext{
${ }^{46}$ Abū-Ḥāmid Muḥammad Ibn-Muhammad al-Ġazzālī, Iḥyā' 'ulūm ad-dīn, aț-Ṭab a 2, muṣaḥhạa, munaqqaḥa, wa-mazīda. (Ǧidda: Dār al-Minhāğ li-'n-Našr wa-'t-Tauzī', 2013). 17.

${ }_{47}$ Bingka-bingka in the Mandailing understanding is the jealousy act to see someone's effort succeed.
} 
namely circumcision, shaving pubic hair, cutting mustache, cutting nails, and pulling underarm hair" (HR. Bukhari and Muslim). The five organs mentioned in this hadith are vulnerable to germs. Nails for example if we keep them long then various types of dirt will be lodged in it so that they will be easily enter to the human body and cause various types of diseases.

Paias pamatangmu is an advice to clean the body in the tradition of the AngkolaMandailing people is very relevant to education. The tradition of giving advice basically aims to make students and the community look clean and comfortable when making a good social interaction.

1) Paias Parabitonmu

Clothing is basically functions as a cover for one's body. Clothing aims to protect someone from hot or cold weather. Along with the times, clothing also functioned as an ornament to beautify the appearance, so it becames a mode how to describe the true identity of one's self. In Islam, clothing basically functions to cover the whole body so as not to be seen by people whose are forbidden to see them. In addition, it is also a legal requirement in carrying out worship. Allah SWT states in Al-Qur'an "O children of Adam, We have bestowed upon you clothing to conceal your private parts and as adornment. But the clothing of rightteousnessthat is best. That is from the signs of Allah that perhaps they will remember." (Surah Al-A'raf: (7): 26).

The function and purpose of the clothing mentioned above will not be perfect if the clothes worn are dirty, smelly or unclean. So that the cleanliness of clothing is also part of the perfection in wearing it. The importance of advice to clean clothes in Islam is very essential. Allah SWT states in Al-Qur'an "And your clothing purify" (QS AlMuddassir : (74) : 4). M. Quraish Shihab in his interpretation stated that basically the order to clean this was on the clothes worn, so that they remains clean, comfortable and good looking. ${ }^{48}$

Based on the explanation above it can be stated that paias parabiton as the local wisdom of Angkola-Mandailing people is related to the virtue values. Because cleanliness of clothes is also an essential thing in life. A person can be considered honorable if the clothes he wears are clean and beautiful. So it can be understood that implementing character building to get used to live in a clean condition is an important thing in the education.

4) Paias bagasmu

House is basically a residence of a family, a place to return when someone travels. House is a source of peace, harmony and inspiration of the owner. House in Islamic view can be seen in Al-Qur' an "And Allah has made for you from your homes a place of rest and made for you from the hides of the animals tents which you find light on your day of travel and your day of travel and your

48 M. Quraish Shihab and M. Quraish Shihab, Surah ash-Shaff, Surah al-Jumu'ah, Surah alMunâfiqûn, Surah at-Taghâbûn, Surah ath-Thalâq, Surah at-Tahrîm, Surah al-Mulk, Surah al-Qalam, Surah alHâaqqah, Surah al-Ma ârij, Surah Nûh , Surah al-Jinn, Surah al-Muzzammil, Surah al-Muddatstir, Surah alQiyâmah, Surah al-Insân, Surah al-Mursalât, Fifth Edition., Tafsîr Al-Mishbâh Pesan, Kesan, dan Keserasian al-Qur'an / M. Quraish Shihab ; 14 (Jakarta: Lentera Haiti, 2012), p. 554. 
day of encapment; and from their wool, fur and hair is furnishing and enjoyment for a time " (Surat AlNahl : ( 16 ) : 80). Calmness and peace are the key for everyone who wants to succeed in achieving their goals. When anxiety and nervous arise in dealing with something, it is necessary to look for a place where a sense of security and peace can be felt. And house becomes the first reference.

The above view hints that the house has to be clean and protected from all dirt and noise. Because the characteristics of the peaceful house is that there are no scattered trash and loudly noise from useless conversations. The Arabic proverb says baiti jannati my house is my paradise. The meaning contained in the proverb shows that the house has a very deep meaning in the process of living life in this world.

Paias bagasmu, cleaning your house in the view of Angkola-Mandailing people is a tradition of the community in general to pay attention to the cleanliness of each house. Marsipature hutana be dohot marsipature bagasna be, repairing their hometowns and houses is a view that shows the people of Angkola-Mandailing are very concerned about peace and calmness at home. So when leading the process of life and education a person get the support by the presence of home which is safe, clean and quiet. In this context it can be said that the advice paias bagasmu is relevant to be encouraged.

5) Paias Pakaranganmu

Pakarangan here is narrowly interpreted as home yards, gardens in the house and the environment around the house. Angkola-Mandailing people usually work together to clean the yard of a house with the intention to make guests and relatives feel comfortable when will do oral tradition such as markobar or discussion in weddings and so on.

In Islamic view, the advice to clean up the yard is not only the yard in the narrower context but also the yard in a broader context, such as the environment both on land and sea. The consequences when humans do not pay attention to the cleanliness of the environment will receive bad consequences such as natural disasters. Allah SWT states in AlQur'an "Corruption has appeared throughout the land and sea by (reason of) what the hands of people have earned so He may let them taste part of (the consequences of) what they have done that perhaps they will return (to righteousness)" (Surat Al-Rum: (30): 41).

Based on the view above, it can be understood that the yard or the environment becomes part of human life, this can be stated that human life can not be separated from the environmental conditions where they live. So that environmental cleanliness reflects happiness, prosperity, comfort and safety life from various natural disasters.

\section{CONCLUSION}

Poda $\mathrm{Na}$ Lima is a local wisdom of the Angkola-Mandailing community which is basically a philosophy of life in shaping the religious character as aspired by the Indonesian people. The values contained in Poda Na Lima are basically provide guidance how to organize 
life to be better and more honorable. The advice to maintain cleanliness in each point of Poda Na Lima is good both mentally and physically shows that local wisdom becomes the universal values in every line of human life. So, in the context of character building process, both at school and the community, local wisdom needs to be "turned on" back in order to remind students and society about their local culture and actualized in daily life.

In general, this research is only to the extent of Islamic values of Poda Na Lima that shape the religious character of the Angkola-Mandailing community. There are still many aspects that need to be revealed in Poda Na Lima to be known by the public in general. So that further research can be done by looking at the practice of Poda Na Lima in the traditional customs events of Angkola-Mandailing then how the role of the dalihan na tolu (three stoves) as a term to describe the system of kinship of the Angkola-Mandailing people in practicing Poda $\mathrm{Na}$ Lima in the customs processions and daily life.

\section{REFERENCES}

Adisusilo, S., Pembelajaran Nilai Karakter Jakarta: Rajawali Pers, 2012.

Asriati, Nuraini, "Mengembangkan Karakter Peserta Didik Berbasis Kearifan Lokal Melalui Pembelajaran di Sekolah", Jurnal Sosiologi Pendidikan dan Humaniora, Vol. 3. No. 2. Oktober 2012.

Al-Ġazzālī, Abū-Ḥāmid Muhammad Ibn-Muhammad, Iḥyā' 'ulūm ad-dìn, aț-Ṭab'a 2, mușaḥaḥa, munaqqaḥa, wa-mazīda. Ğidda: Dār al-Minhāğ li-'n-Našr wa-'t-Tauzī' , 2013.

Budiyono, et all., "Menggali Nilai-nilai Kearifan Lokal Budaya Jawa sebagai Sumber Pendidikan Karakter", Prosiding Seminar Nasional Bimbingan dan Konseling, Vol. 1, No. 1, 2017.

Harahap, Basyral Hamidi, Siala Sampagul: Nilai-nilai Luhur Budaya Masyarakat Kota Padang Sidimpuan, cet. Pertama, Bandung: Pustaka, 2004.

Harahap, Basyral Hamidi, and Hotman M. Siahaan, Orientasi Nilai-nilai Budaya Batak: Suatu Tindakan Terhadap Perilaku Batak Toba dan Angkola Mandailing, Jakarta: Sanggar Williem Iskander, 1987.

Hasbullah, et all., “Analisis Pengelolaan Sampah di Kota Subulussalam Tahun 2017”, Jurnal Jumantik, Vol. 4, No. 2, 2019.

Iswatiningsih, Daroe, "Penguatan Pendidikan Karakter Berbasis Nilai-nilai Kearifan Lokal di Sekolah" Jurnal Satwika (Kajian Ilmu Budaya dan Perubahan Sosial), Vol. 3, No. 2, 2019.

Iskander, Willem, Sibulus-bulus Sirumbuk-rumbuk, Basyral Hamidi Harahap, translation, 44th edition, Jakarta: Puisi Indonesia, 1987.

Kamisa, Kamus Besar Bahasa Indonesia: Edisi Terbaru, Dilengkapi Ejaan Yang Disempurnakan dan Kosa Kata Baru, Surabaya: Cahaya Agency, 2017.

Kementerian Pendidikan dan Kebudayaan, Modul Pelatihan Penguatan Pendidikan Karakter bagi Komite, 2017. 
Kuntoro, Sodiq A., “Konsep Pendidikan Berbasis Kearifan Lokal Sebagai Dasar Pembentukan Karakter Bangsa", Prosiding Seminar Nasional Ilmu Pendidikan: Pengembangan dan Pengelolaan Pendidikan Berbasis Kearifan Lokal, First edition, 2012.

Latif, Yudi, Negara Paripurna: Historisitas, Rasionalitas, dan Aktualitas Pancasila, Fifth edition, Jakarta: PT Gramedia Pustaka Utama, 2015.

Mardikantoro, Hari Bakti, “Bahasa Jawa sebagai Pengungkap Kearifan Lokal Masyarakat Samin di Kabupaten Blora", Jurnal Komunitas, Vol. 5, No. 2, 2013.

Machasin and Abdul Wahid Hasan, Islam Dinamis Islam Harmonis: Lokalitas, Pluralisme, Terorisme, First edition. Yogyakarta: Penerbit \& Distribusi, LKiS, 2011.

Madjid, Nurcholish, "Akhlak: Esensi Kejadian Manusia”, dalam Budhy Munawar Rachman, Ensiklopedi Nurcholish Madjid, First edition, Jakarta: Teraju, 2005.

Majid, Nurcholish, Tradisi Islam: peran dan fungsinya dalam pembangunan di Indonesia Jakarta; Dian Rakyat: Paramadina ;, 2008.

Majid, Nurcholish, and Budhy Munawar Rachman, Ensiklopedi Nurcholish Madjid: Pemikiran Islam Di Kanvas Peradaban, First edition. Jakarta: Paramadina, 2006.

Naser, M. Nikman, "Konselor dalam Penguatan Nilai dan Moral: Strategi Membentuk Generasi Religius", Jurnal Ilmiah Syiar, Vol. 19, No. 01, 2019.

Rahyono, FX, Kearifan Budaya dalam Kata, Jakarta: Wedatama Widyasastra , 2009.

Shihab, M. Quraish, Wawasan Al-Qur'an: Tafsir Tematik atas Pelbagai Persoalan Umat, First edition, Bandung: Mizan, 2013.

Shihab, M. Quraish, and M. Quraish Shihab, Surah ash-Shaff, Surah al-Jumu'ah, Surah alMunâfiqûn, Surah at-Taghâbûn, Surah ath-Thalâq, Surah at-Tahrîm, Surah al-Mulk, Surah alQalam, Surah al-Hâaqqah, Surah al-Ma ârij, Surah Nûh, Surah al-Jinn, Surah al-Muzzammil, Surah al-Muddatstir, Surah al-Qiyâmah, Surah al-Insân, Surah al-Mursalât, Fifth edition., Tafsîr Al-Mishbâh Pesan, Kesan, dan Keserasian al-Qur'an / M. Quraish Shihab ; 14 Jakarta: Lentera Haiti, 2012.

Sugiyono, Metode Penelitian Pendidikan: Pendekatan Kuantitatif, Kualitatif, dan RED, Seventh edition, Bandung: Alfabeta, 2010.

Sidabolak, Alimuddin, et all., Hasil Sensus Penduduk 2010 Provinsi Sumatra Utara: Data Agregat per Kabupaten/Kota, Badan Pusat Statistik Provinsi Sumatra Utara 2010.

Sternberg, Robert J, Wisdom and Gifiedness dalam Shavinina, Larissa V, Ferrari, Michel Ed. Beyond Knowledge Extra Cogtitive Aspects of Developing Hight Ability, New Jersey: Lawrence-Erlbaum, 2004.

Syukur, M. Amin, et all., Tasawuf Kontekstual; Solusi Problem Manusia Modern, Second edition, Yogyakarta; Pustaka Pelajar, 2002.

Saifudin Ansari, Ending, Wawasan Islam, Third edition, Bandung: Pelajar, 1982. 
Thamrin, Husni, "Revitalisasi Kearifan Lokal Melayu dalam Menjaga Harmonisasi Lingkungan Hidup", Jurnal Toleransi: Media Komunikasi Umat Beragama, Vol. 6, No. 1, 2014.

Yunus, Mahmud, Kamus Arab-Indonesia, Jakarta; PT Mahmud Yunus Wadzuryah, 1989.

Zamzami Elamin, Muchammad, et all., "Analisis Pengelolaan Sampah pada Masyarakat Desa Disanah Kecamatan Sreseh Kabupaten Sampang", Jurnal Kesehatan Lingkungan, Vol. 10, No. 4, 2018. 